\title{
Pedamuk Menciptakan Lingkungan Sekolah Menuju Revolusi Industri 4.0
}

\author{
Deny Nusyirwan'), Muhammad Bayu Purnama²) \\ 1,2) Jurusan Teknik Elektro Universitas Maritim Raja Ali Haji (UMRAH) \\ ${ }^{1)}$ denynusyirwan@umrah.ac.id
}

DOI: http://dx.doi.org/10.21107/rekayasa.v12i1.5105

\begin{abstract}
ABSTRAK
Sampah menjadi permasalahan yang dapat menimbulkan dampak buruk bagi masyarakat, Permasalahan sampah dimulai sejak meningkatnya jumlah manusia dan hewan penghasil sampah (Suyono dan Budiman, 2010). Sampah menyebabkan berkembangnya beragam penyakit, terutama penyakit yang dibawa oleh vektor, yakni organisme penyebar agen pathogen dari inang ke inang, seperti nyamuk yang banyak menularkan penyakit. Demam Berdarah Dengue (DBD) atau Dengue Haemorrhagic Fever (DHF) merupakan salah satu penyakit yang disebabkan oleh nyamuk spesies Aedes Aegypti dan aedes albopictus (DBD, 1999) sebagai vector primer, serta Aedes polynesiensis, Aedes scutellaris serta Ae (Finlaya) niveus sebagai vektor sekunder. Dengan permasalahan tersebut, maka penelitian ini membahas tentang solusi yang efektif untuk mendeteksi nyamuk sebagai solusi pencegahan nyamuk di lingkungan sekolah. Penelitian ini membahas tentang bagaimana kesadaran masyarakat di lingkungan sekolah terhadap sampah yang dapat menyebabkan nyamuk berkeliaran dan meningkatkan korban penderita DBD (Demam Berdarah Dengue) pada anak-anak. Pendeteksi ini menggunakan Arduino Uno sebagai kontroller, Sensor Ultrasonik sebagai pendeteksi nyamuk, Serial Monitor sebagai alat pantau nyamuk. Dengan demikian, kesadaran dan kepedulian para siswa terkhususnya anak sekolah terhadap penanggulangan sampah akan meningkat dari sebelumnya. Inovasi ini juga dapat menjadi inovasi yang dapat menuju revolusi industri 4.0, karena lebih mengenalkan teknologi berbasis digital kepada anak sekolah.
\end{abstract}

Kata Kunci: Sampah, nyamuk, pendeteksi nyamuk, kesadaran anak sekolah, penanggulangan, revolusi industri 4.0

\section{Pedamuk Create A Quality School Of Environment Towards Industrial Revolution 4.0}

\begin{abstract}
Waste becomes a problem that can cause adverse effects to the community, the problem of waste is started from the increasing number of people and waste-producing animals (Suyono and Budiman, 2010). Garbage will develop a variety of diseases, especially those carried by vectors, namely pathogenic agents that spread from host to host, such as mosquitoes which transmit diseases. Dengue Haemorrhagic Fever (DHF) is one of the diseases caused by mosquitoes Aedes Aegypti and Aedes albopictus species (DHF, 1999) as primary vectors, and Aedes polynesiensis, Aedes scutellaris and Ae (Finlaya) niveus as vectors secondary. With these problems, this study discusses an effective solution to detect mosquitoes as a mosquito prevention solution in the school environment. This study discusses how public awareness in the school environment is about waste that can cause mosquitoes to roam and increase victims of dengue fever (Dengue Hemorrhagic Fever) in children. This detector uses Arduino Uno as a controller, Ultrasonic Sensor as a mosquito detector, Serial Monitor as a tool to monitor mosquitoes. Thus, the awareness and concern of the students especially the school children towards waste management will increase from before. This innovation can also be an innovation that can lead to a 4.0 industrial revolution because it introduces more digital-based technology to school children.
\end{abstract}

Keywords: Waste, mosquito, mosquito detection, awareness of school children, countermeasures, industrial revolution 4.0

\section{Article History:}

Received: Maret 2019; Accepted: April 2019

ISSN: 2502-5325 (Online) Terakreditasi Peringkat 4 oleh Kementerian Riset, Teknologi dan Pendidikan Tinggi (ARJUNA) berdasarkan Keputusan Direktur Jenderal Penguatan Riset dan Pengembangan Nomor: 21/E/KPT/2018 tanggal 9 Juli 2018

\section{Cite this as:}

Nusyirwan, D., \& Purnama, M. (2019). Pedamuk Menciptakan Lingkungan Sekolah Menuju Revolusi Industri 4.0. Rekayasa, 12(1), 49-58. doi:http://dx.doi.org/10.21107/rekayasa. v12i1.5105

C 2019 Universitas Trunojoyo Madura 


\section{PENDAHULUAN}

Pencemaran, menurut SK Menteri Kependudukan Lingkungan Hidup No 02/MEN$\mathrm{KLH} / 1988$, adalah masuk atau dimasukkannya mahluk hidup, zat, energi, atau komponen lain ke dalam air atau udara. Untuk mencegah terjadinya pencemaran terhadap lingkungan oleh berbagai aktivitas industri dan aktivitas manusia, maka diperlukan pengendalian terhadap pencemaran lingkungan dengan menetapkan baku mutu lingkungan. Baku mutu lingkungan adalah batas kadar yang diperkenankan bagi zat atau bahan pencemar terdapat di lingkungan dengan tidak menimbulkan gangguan terhadap makhluk hidup, tumbuhan atau benda lainnya (Sidar, 2014).

Permasalahan sampah dimulai sejak meningkatnya jumlah manusia dan hewan penghasil sampah (Suyono dan Budiman, 2010). Volume sampah yang dihasilkan di kota Surakarta semakin naik dari tahun ke tahun. Pada tahun 2011 naik 2x lipat dari tahun 2010. Volume sampah pada tahun 2011 sebanyak 280 ton/hari. Tahun 2012 volume naik sekitar $7 \%$ menjadi 300 ton/hari. Sedangkan tahun 2013 diperkirakan naik 10\% dari tahun 2012 (Widodo, 2012).

Indonesia merupakan negara beriklim tropis yang sangat baik untuk pertumbuhan hewan maupun tumbuhan. Indonesia juga tempat berkembangnya beragam penyakit, terutama penyakit (Pusdatin Kemenkes, 2018 ) yang dibawa oleh vektor, yakni organisme penyebar agen pathogen dari inang ke inang, seperti nyamuk yang banyak menularkan penyakit. Demam Berdarah Dengue (DBD) atau Dengue Haemorrhagic Fever (DHF) merupakan salah satu penyakit yang disebabkan oleh nyamuk spesies Aedes Aegypti dan aedes albopictus (DBD, 1999) sebagai vector primer, serta Aedes polynesiensis, Aedes scutellaris serta Ae (Finlaya) niveus sebagai vektor sekunder. Biasanya juga terjadi penularan transsexual dari nyamuk jantan ke nyamuk betina melalui perkawinan (WHO, 2009) serta penularan transovarial dari induk nyamuk ke keturunannya (Josi dan Sharma, 2001).

Demam Berdarah Dengue (DBD) biasanya terjadi pada musim penghujan maupun pancaroba. Wilayah penyebaran penyakit DBD semakin lama semakin meluas, hingga tahun 2014, tercatat penderita penyakit DBD di 34 provinsi di Indonesia sebanyak 71.668 jiwa, dan 641 di antaranya meninggal dunia (PKP Kemenkes RI, 2015). Data Dinas Kesehatan Kabupaten Bogor tahun 2015 menunjukkan jumlah kasus penyakit DBD sebesar 1.313 kasus, dengan rincian penderita tertinggi pada golongan umur 15-44 tahun sebanyak 882 penderita dan golongan umur 5-14 tahun sebanyak 558 penderita (Dinkes Kab. Bogor, 2015).

Kelompok anak sekolah menjadi pusat perhatian yang sangat penting karena jumlahnya termasuk ke dalam persentase penderita tertinggi. (Notoatmodjo, 2005) berpendapat anak sekolah sebagai kelompok yang mudah untuk dibimbing, diarahkan, dan ditanamkan kebiasaan-kebiasaan baik. Siswa sebagai sasaran penyuluhan kesehatan merupakan aset strategis dalam pencegahan penyakit DBD. Dengan demikian, sektor pendidikan harus menjadi mitra penting instansi kesehatan dalam promosi kesehatan (Jayawardene et al., 2011).

Kebersihan lingkungan sekolah adalah peran yang sangat penting, perilaku ini merupakan kewajiban bagi seluruh warga sekolah dalam menjaga lingkungan tersebut agar tetap bersih dan bebas sampah. Jika lingkungan sekolah kotor, seluruh warga sekolah merasa tidak nyaman dalam melakukan segala aktifitasnya disekolah. Salah satu contohnya adalah kurang berkonsentrasi dalam belajar maupun mengajar dan mengancam kesehatan akibat lingkungan yang tidak baik. Adapun cara menjaga kebersihan lingkungan sekolah adalah dengan membuang sampah pada tempatnya, selalu melaksanakan piket kelas dengan baik, dan melakukan gotong royong di lingkungan sekolah (Siska, 2015).

Dampak buruk yang terjadi akibat lingkungan sekolah yang tidak baik adalah dapat menimbulkan penyakit, seperti contohnya Demam Berdarah (Balitbang Kemenkes, 2016) atau juga infeksi virus nyamuk akibat lingkungan yang kotor. Ini disebabkan karena banyaknya tumpukan sampah yang ada di lingkungan sekolah, menyebabkan kualitas lingkungan menjadi pengaruh besar dalam kesehatan dan keselamatan warga sekolah (Situan, 2016). Untuk menjawab permasalahan yang terjadi, maka dapat difikirkan solusi efisien untuk mengatasi permasalahan tersebut.

PEDAMUK (Pendeteksi Nyamuk) adalah solusi yang tepat dalam mengatasi permasalah 
nyamuk, yang menggunakan Sensor Ultrasonik (sensor jarak) untuk mendeteksi suara nyamuk dan intetitas nyamuk yang berkeliaran dilingkungan sekolah. PEDAMUK sangat membantu dalam mencari solusi selanjutnya untuk menanggulangi penyebab timbulnya sarang nyamuk, salah satunya adalah menjaga kebersihan lingkungan dengan membuang sampah pada tempatnya. Proses ini adalah merupakan langkah untuk menciptakan lingkungan sekolah berkualitas menuju revolusi industri 4.0 untuk Indonesia cerdas

\section{METODE PENELITIAN \\ Metode Penulisan}

Metode penulisan ini menggunakan metode Proses Desain Rekayasa (Engineering Design Process), yang terdiri dari metode observasi, wawancara dan studi literature seperti yang ditampilkan pada gambar 1 .

\section{Lokasi Penelitian}

Lokasi penelitian dilakukan di SMPN 11 Kampung Bugis Kecamatan Kampung Bugis Kelurahan Tanjungpinang Kota Kepulauan Riau.

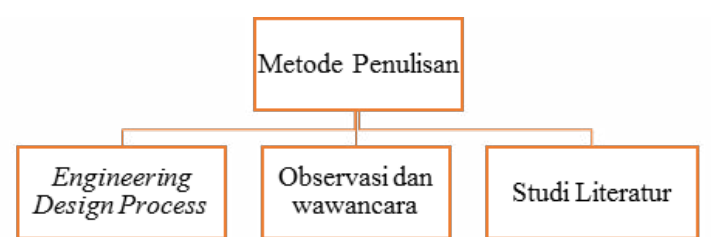

Gambar 1. Diagram Blok untuk Metode Penulisan

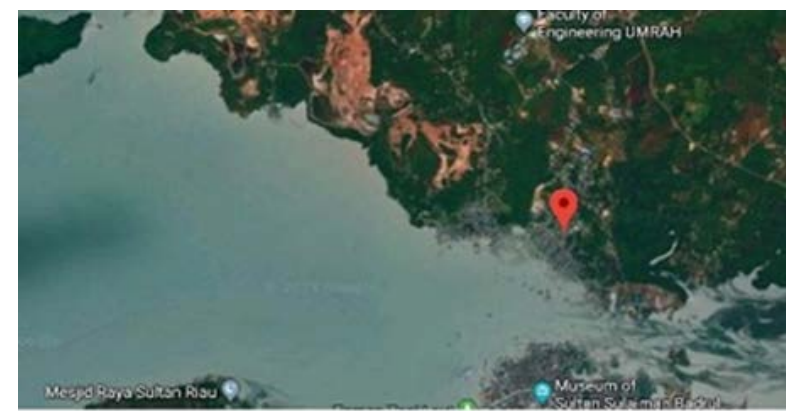

Gambar 2. Lokasi kampung nelayan kampung bugis di kota tanjung pinang (https://www. google.com/maps, diakses 31 Maret 2019)

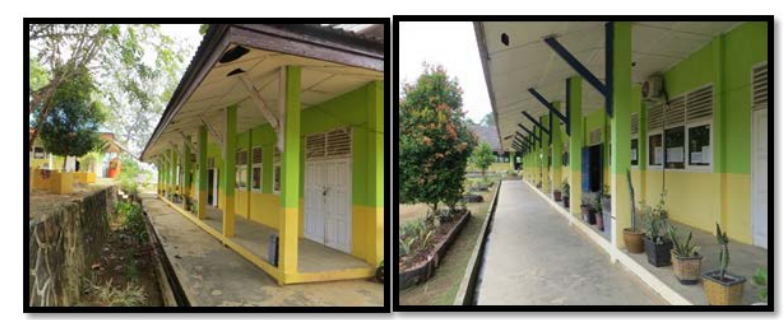

Gambar 3. Lingkungan SMPN 11 Kampung Bugis
Pada gambar 2 menampilkan lokasi kampung Bugis di pesisir kota Tanjungpinang.. Sedangkan pada gambar 3, menampilkan Lingkungan SMPN 11 Kampung Bugis

\section{Metode Perancangan}

Metode perancangan adalah langkah-langkah pembahasan yang akan dibahas beserta hasil penelitian sebagai berikut:

Pada Gambar 4 menunjukkan konsep perancangan yang dimulai dengan etnografi untuk mendapatkan informasi secara luas terhadap daerah yang sedang di amati, selanjutnya akan dilakukan brainstorming problems. Pada tahapan ini setiap permasalahan yang ditemukan akan di sampaikan dan di catat. Penentuan permsalahan utama (define main problem) adalah merupakan langkah yang menentukan pada tahapan Engineering Design Process selanjutnya, yaitu menentukan solusi dan pembuatan purwarupa dan pengujian.

Jenis Data yang Digunakan

Jenis data yang digunakan berupa data primer dan sekunder. Data primer diperoleh dari hasil penelitian. Sedangkan data sekunder diperoleh dari studi literatur.Seperti tampilan pada gambar 5 .

\section{Metode Pengumpulan Data}

Metode pengumpulan data yang digunakan adalah metode etnografi, dimana peneliti akan berintegrasi langsung dengan objek untuk melakukan pengamatan secara langsung di SMPN 11 Kampung Bugis Kecamatan Kampung Bugis Kelurahan Tanjungpinang Kota Kepulauan Riau. Metode

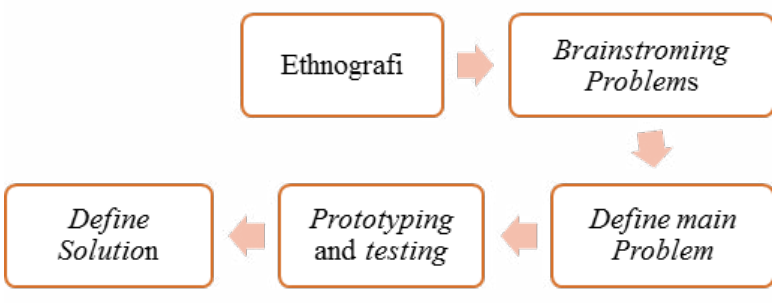

Gambar 4. Blok Diagram Konsep Perancangan

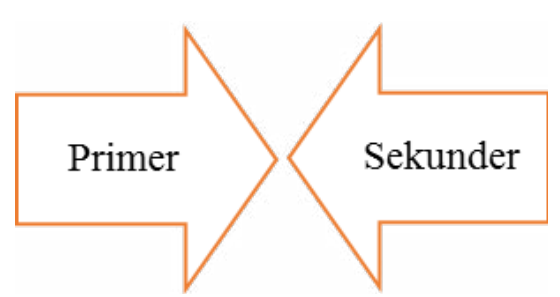

Gambar 5. Jenis Data yang Digunakan 


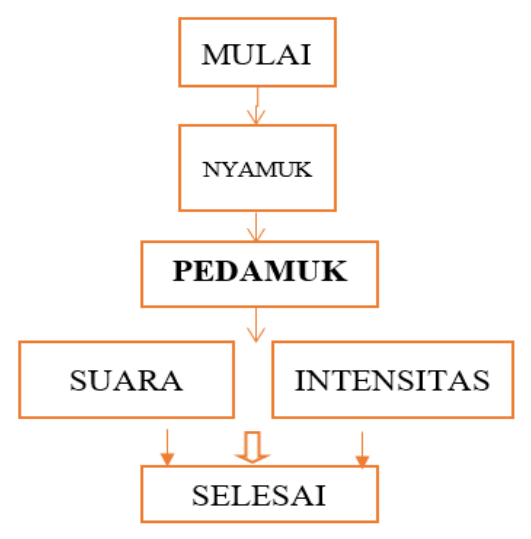

Gambar 6. Kerangka Berfikir

pengumpulan informasi dilakukan dengan melakukan tahap observasi secara terbuka. Proses berintegrasi dengan beberapa siswa adalah usaha untuk mendapatkan informasi yang banyak (kuantitatif) dengan tujuan sebagai penyempurnaan inovasi.

\section{Kerangkan Berfikir}

Kerangka berfikir adalah suatu proses yang mencakup proses awal dan proses akhir. Dalam mewujudkan kerangka berfikir tersebut dibutuhkan sistem perancangan gagasan guna mewujudkan pemikiran lanjutan yang akan dikembangkan,: Gambar 6 menjelaskan permasalahan nyamuk yang ada pada lingkungan sekolah selanjutnya akan di hasilkan sebuah inovasi yang berbasiskan teknologi PEDAMUK (Pendetksi Nyamuk). Informasi akan diberikan dalam bentik tampilan layar untuk jumlah nyamuk dan suara (bunyi) untuk menandakan bahwa terdapat nyamuk.

\section{HASIL DAN PEMBAHASAN}

\section{A. Proses Desain Rekayasa (Engineering Design Process)}

Teknologi yang dihasilkan adalah merupakan solusi terhadap permasalahan yang ada pada masyarakat di suatu daerah. Untuk mendapatkan solusi yang tepat diiperlukan data yang lengkap, oleh sebab itu diperlukan tahapan Proses Design Rekayasa (Engineering Design Process) yang tepat pula.

Penelitian ini dimulai dengan observasi di sekolah, wawancara atau interview. Selanjutnya dilakukan tahapan brainstorming untuk mendapatkan beberapa solusi dari permasalahan. Tahapan sketching dan pembuatan purwarupa sederhana diperlukan untuk mendapatkan bentuk rancangan yang sesuai. Tahapan pengujian purwarupa serta pengalaman pengguna untuk mendapatkan

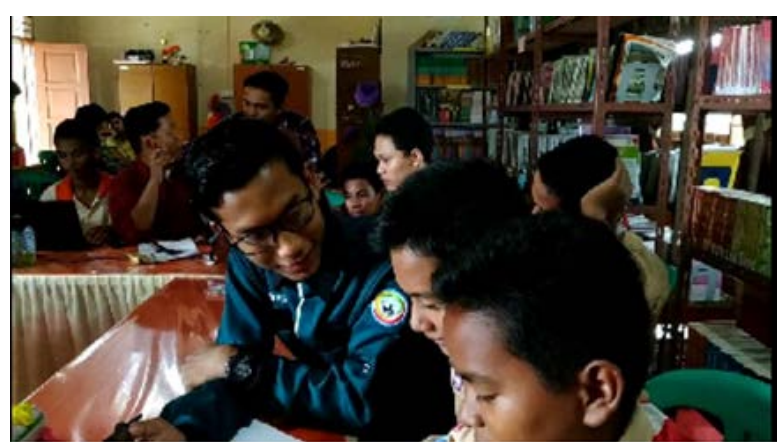

Gambar 7. peneliti yang berpartisipasi aktif mengikuti kegiatan dan aktivitas bersama sekelompok pelajar dari sekolah di SMPN 11 Kampung Bugis

masukan dari calon pengguna yang akan dipergunakan untuk memperbaiki rancangan sebelumnya (apabila diperlukan). Keseluruhan tahapan ini disebut Engineering Design Process.

\section{Etnografi}

. Etnography adalah merupakan bagian awal dari EDP, dimana dalam observasi tahapan ini diperlukan pendekatan secara sosial dan memerlukan jangka waktu tertentu didalam pelaksanaannya di lapangan. Pendekatan secara sosial berupa hidup bersama di lingkungan masyarakat dan melakukan aktifitas seperti biasa di masyarakat setempat. Selanjutnya melakukan pendataan mengenai pola hidup masyarakat tersebut yang akan dijadikan sebagai masukan untuk inovasi berbasiskan teknologi.

Dengan metode observasi yang berbasiskan etnografi, peneliti akan dapat mengumpulkan data secara lengkap dengan melihat dan mengalami secara langsung peristiwa dan kondisi apa yang terjadi, hal ini sangat dianjurkan karena kesulitan yang dialami oleh pengguna untuk mengekspresikan kebutuhan dan keinginan mereka (J. Blindheim, 2016).

Metode etnografi yang diterapkan pada penelitian ini adalah peserta sebagai peneliti (participant as observer), dimana peneliti ikut serta didalam kelompok yang sedang diteliti (C. Wagner, 2012). Pada gambar 7 memperlihatkan sekelompok mahasiswa sebagai peneliti yang berpartisipasi aktif mengikuti kegiatan dan aktivitas bersama sekelompok pelajar dari sekolah di SMPN 11 Kampung Bugis. Kelompok yang sedang diteliti mengetahui mengenai penelitian. Dengan metode ini maka peneliti dan kelompok yang diteliti akan lebih dekat dan terbuka sehingga timbul 


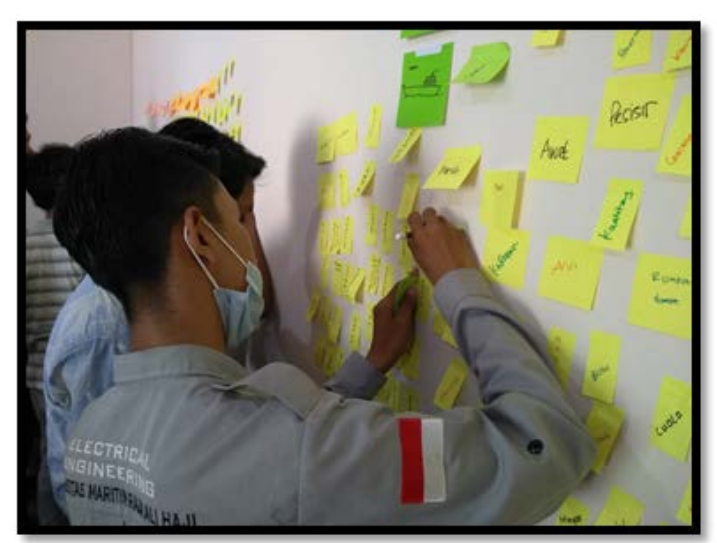

Gambar 8. Menampilkan Permasalahan yang dtemukan di sekolah

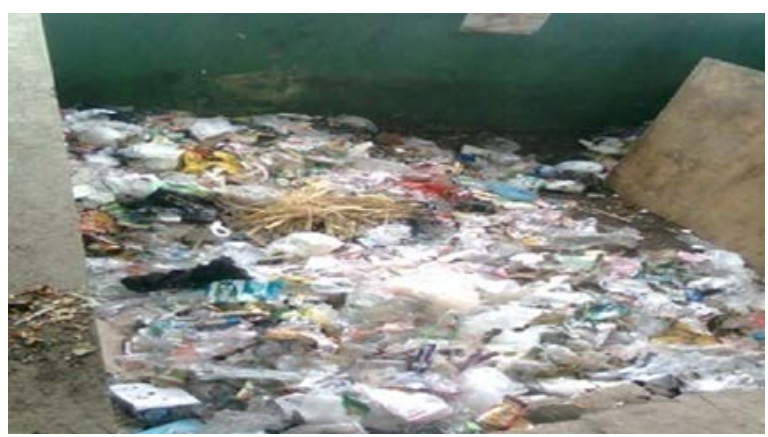

Gambar 9. Sampah sebagai rmasala utama di SMP N 11 Kampung Bugis

saling percayaan, pada ahirnya akan memberikan informasi yang lebih dalam.

\section{Curahan gagasan permasalahan}

Pola penyampaian gagasan melalui curahan gagasan (Brainstorming) sangat diperlukan untuk memotivasi peserta mampu berpikir inovatif dan kratif. Curahan gagasan yang bersifat luas (divergence) adalah merupakan pondasi untuk inovasi yang berbasiskan teknologi, hal ini sering dipahami dengan T concept di dalam bidang rekayasa (engineering), dimaksudkan bahwa inovasi yang dihasilkan memiliki pengaruh yang luas dan mendalam. Setelah melakukan observasi, langkah selanjutnya adalah menentukan permasalahan, oleh sebab itu diperlukan proses pengerucutan atau dikenal convergence process. Sebagai langkah awal adalah menentukan masalah-masalah yang kemudian dikelompokkan dan dipilih 1 (satu) masalah utama. Pada Gambar 8 dapat dilihat sekelompok peneliti sedang melakukan proses convergence dengan menggunakan metode brainstorming

\section{Menentukan masalah utama}

Setelah melakukan Brainstroming problems kemudian dilanjutkan dengan proses curahan gagasan untuk menentukan permasalahan inti dari semua permasalahan yang disampaikan.

Permasalahan utama adalah permasalahan yang akan di angkat untuk langkah penentuan solusi, dalam tahapan ini akan di pilih satu masalah saja. Proses diskusi bersama sesama anggota kelompok, selanjutnya memberikan penjelasan terhadap masalah yang akan dijadikan masalah utama. Dalam proses ini perlu dipertimbangkan adalah keputusan yang akan diambil adalah merupakan keputusan bersama anggota lainnya.

Pada gambar 9 menampilkan tumpukkan sampah sebagai permasalahan utama.

\section{Curahan gagasan solusi}

Langkah selanjutnya adalah proses divergence terhadap permasalahan utama, yaitu proses brainstorming untuk solusi dari masalah utama. Beberapa konsep solusi akan diutarakan melalui proses brainstorming bersama anggota lainnya dengan menggambarkan solusi. Konsep-konsep perancangan tersebut adalah hasil dari brainstorming solusi yang telah fikirkan dan didiskusikan sesama anggota sesuai dengan permasalahan utama.

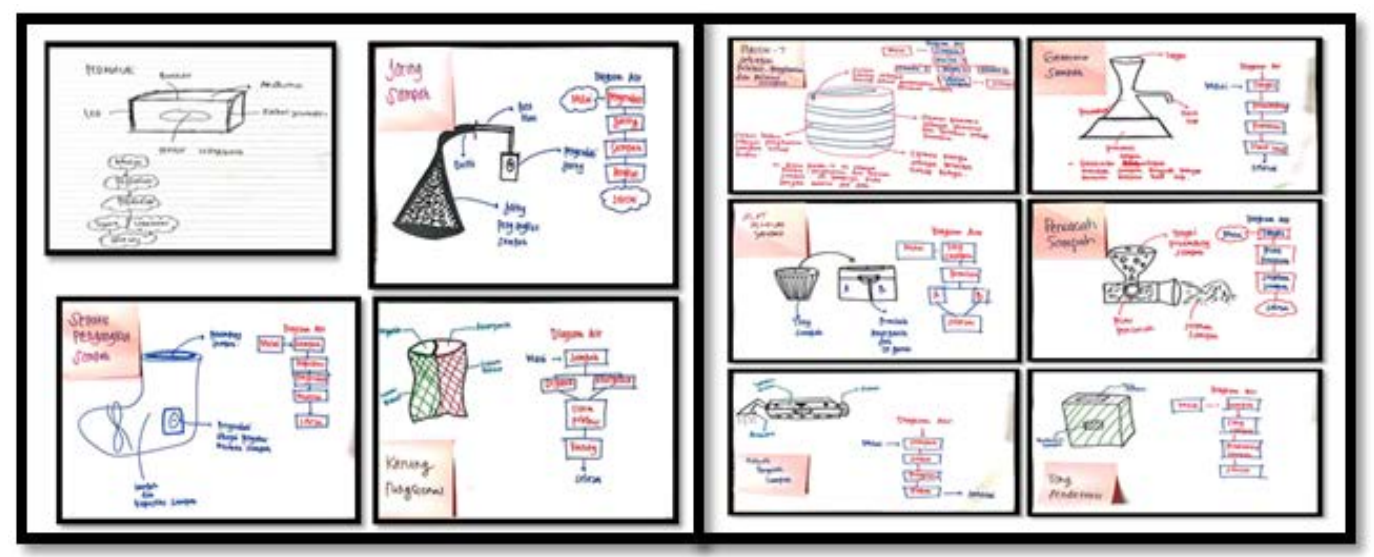

Gambar 10. 10 hasil dari brainstorming solusi yang ditawarkan 
Pada gambar 10 dapat dilihat 10 solusi yang untuk permasalahan tumpukan sampah di lingkungan sekolah. Selanjutnya dari 10 solusi akan didiskusikan kembali bersama anggota kelompok untuk mendapatkan satu solusi terbaik sebagai puncak penyelesaian masalah tumpukan sampah.

\section{Menentukan solusi utama}

Setelah tahapan divergence solution selesai, maka peneliti akan menentukan satu solusi yang akan dijadikan sebagai landasan ke tahapan selanjutnya. Adapun solusi terhadap permasalahan sampah di SMP N 11 Kampung Bugis adalah diperlukan sebuah alat pendeteksi nyamuk (Pedamuk) untuk menanggulangi penyebab timbulnya sarang nyamuk yang selanjutnya diharapkan akan mampu menimbukan kesadaran untuk menjaga kebersihan lingkungan dengan membuang sampah pada tempatnya. Sila lihat gambar 11.

\section{PEDAMUK (PENDETEKSI NYAMUK)}

Gambar 11. Solusi utama

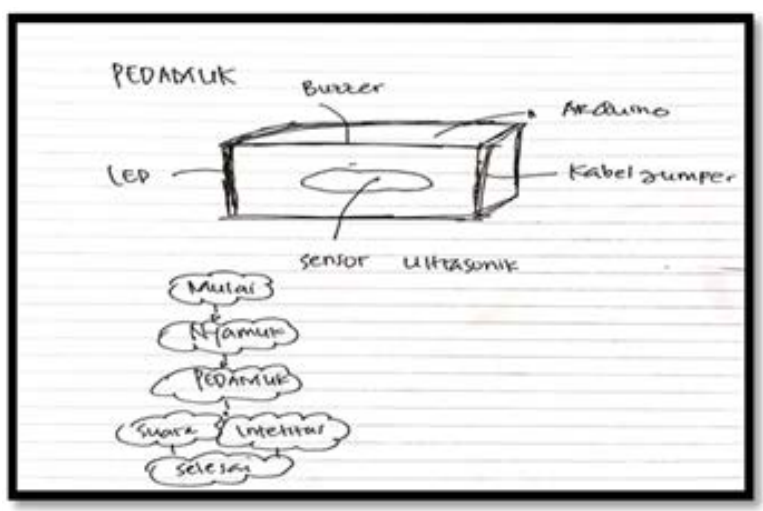

Gambar 12. Sketsa gambar PEDAMUK

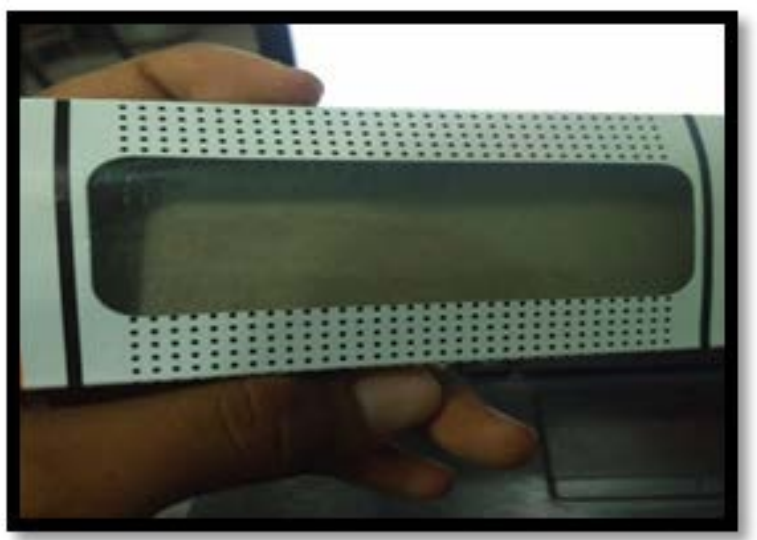

Gambar 13. Prototipe sederhana
PEDAMUK adalah salah satu pemikiran teknologi yang harus dikembangkan, bertujuan untuk mencegah angka terserang penyakit DBD (Demam Berdarah Dengue) bagi anak sekolah, karena saat ini nyamuk berbahaya itu muncul ketika lingkungan kotor, sampah berserakan, dan perawatan kamar mandi yang kurang optimal.

\section{Sketsa solusi utama}

Sketsa (sketching) diperlukan oleh siswa untuk mampu mendorong ide-ide yang bisa disampaikan lewat brainstorming. Sedangkan untuk pengguna teknologi, akan dapat melihat konsep awal dari solusi yang diberikan.diskusi secara internal kelompok dapat dilakukan untuk memberikan masukan terhadap rancangan awal. Sangat didorong untuk menggunakan kertas dan pensil karena akan lebih mudah melakukan perubahan jika ada ide lainnya yang akan dikembangkan. Sketsa dari PEDAMUK dapat dillihat pada gambar 12

\section{Purwarupa Sederhana}

Purwarupa sederhana diperlukan untuk mendapatkan tampilan awal tiga dimensi, Pada penelitian ini akan dirakit sebuah purwarupa sederhana dari bahan yang ekonomis. Hal ini bertujuan untuk mengurangi pengeluaran yang berlebihan ketika terjadi perubahan dalam model yang sedang dikerjakan. Gambar 13 menampilkan purwarupa dari PEDAMUK, pada bagian depan akan ditempatkan sensor jarak yang akan mendeteksi nyamuk.8.

\section{Purwarupa Virtual}

Dalam tahapan ini, telah dimulai menggambar menggunakan komputer untuk mendapatkan tampilan detil awal secara virtual 3 dimensi. Beberapa perubahan dapat dikerjakan secara langsung. Pada gambar 14 menunjukkan proses transformasi dari sketsa yang digambar di atas kertas ke komputer

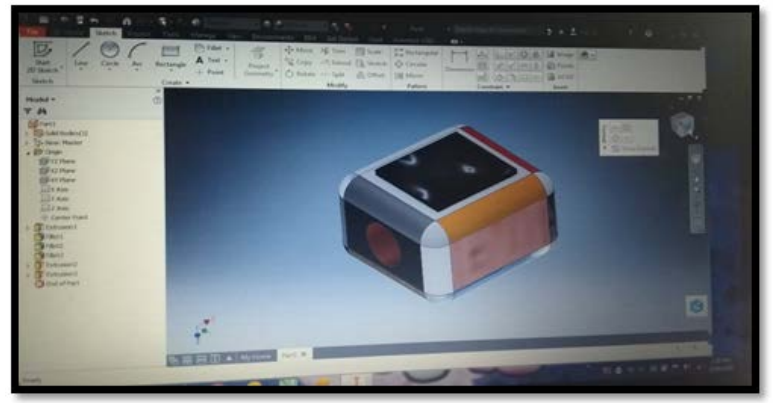

Gambar 14. Prototipe 3D 
Purwarupa di rancang menggunakan aplikasi perangkat lunak Autodesk Inventor. Pada gambar dapat dilihat bahwa PEDAMUK yang sedang dirancang berbentuk segi empat dan pada beberapa bagian akan ditempatkan sensor dan arduino.

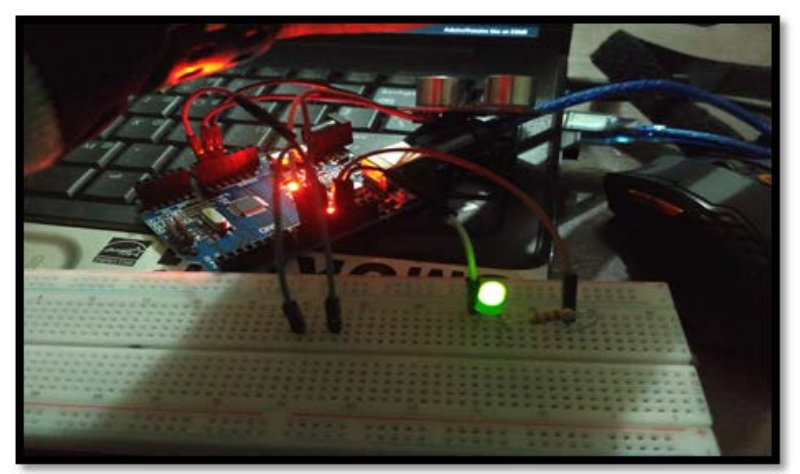

Gambar 15. Purwarupa PEDAMUK (Pendeteksi Nyamuk)

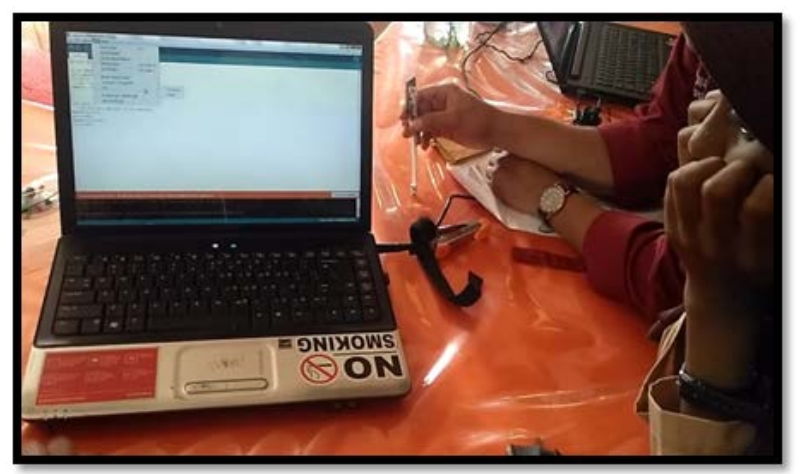

Gambar 16. User testing

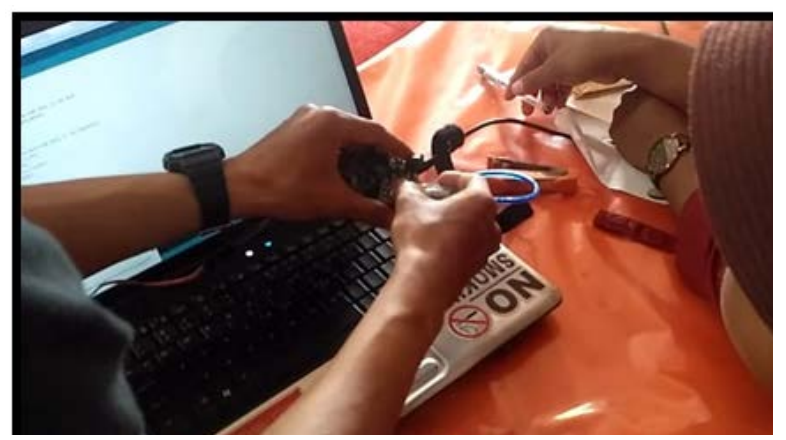

Gambar 17. User experience bersama siswa di sekolah

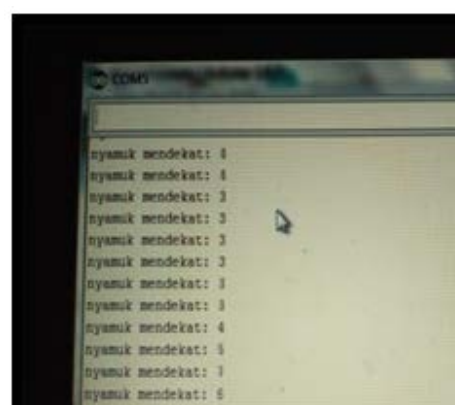

Gambar 18. Respon serial monitor terhadap keberadaan nyamuk

\section{Purwarupa Menengah}

Berikut adalah PEDAMUK dalam bentuk purwarupa menengah dapat dilihat pada gambar 15. PEDAMUK terdiri dari komponen-komponen pendukung seperti Arduino Uno, Sensor Ultrasonik, LED, Kabel Jumper, Buzzer, Resistor, dan komputer. Purwarupa menengah diperlukan untuk mengeksplorasi inovasi didalam proses pengujian kegunaan bersama calon pengguna.

\section{Pengujian kegunaan}

Pengujian kegunaan adalah merupakan tahapan explorasi untuk mendapatkan masukan (feedback) dari calon pengguna terkait solusi yang sedang dikerjakan.. Tahapan ini sangat diperlukan untuk mengetahui kegunaan dari inovasi teknologi yang dirancang sudah tepat sasaran

Pada gambar 16 menampilan proses pengujian purwarupa bersama dengan pengguna, dalam penelitian ini adalah anak sekolah. Proses dimulai dengan pengamatan yang dilakukan oleh beberapa anak sekolah yang tertarik dengan rancangan alat dan mencoba kegunaan. Selanjutnya siswa mulai menanyakan beberapa hal tentang cara kerja dan pandangan siswa tertuju kepada tampilan program dari PEDAMUK. Perilaku ini adalah bentuk reaksi ketertarikan mereka terhadap inovasi ini. Pada penelitian yang berbasis kepada pengguna, proses ini dikenal dengan design with user, dimana proses perancangan dilakukan bersama dengan pengguna

\section{Pengalaman Pengguna}

Inovator yang berbasiskan teknologi sangat sadar bahwa kesuksesan hasil inovasi tidak hanya dilihat dari manfaat dari produk yang akan dihasilkan namun juga perlu memperhatikan faktor pengalaman pengguna (User eXperience). Pengembangan produk tidak lagi hanya untuk mengimplementasikan fitur dan menguji kegunaannya, tetapi juga tentang mendesain produk yang menyenangkan dan mendukung kebutuhan dan nilai-nilai dasar manusia. Dengan demikian, pengalaman pengguna dalam tahapan EDP harus menjadi perhatian utama pengembangan produk (G.I. Johnson, 1989)

User eXperience (UX) akan memperluas pandangan tentang interaksi produk dengan pengguna dari aspek emosional. Adapun motivasi UX adalah untuk mengembangkan pengalaman dan emosi positif. Oleh karena itu, produk harus memenuhi kebutuhan psi- 
kologis dan motif pelanggan (C. von Saucken, 2014).

Pada gambar 17 dapat dilihat bahwa siswa sekolah dapat dengan mudah sudah mengerti terhadap penggunaan inovasi PEDAMUK, siswa terus mencoba inovasi ini karena tertarik dengan purwarupa yang diusulkan. Siswa dapat mengetahui ketika nyamuk terdeteksi oleh sensor maka buzzer akan berbunyi dan pada layar notebook akan menampilkan informasi mengenai keberadaan nyamuk.

\section{Hasil dari pengujian kegunaan dan pen- galaman pengguna.}

Proses pengujian dan pengalaman pengguna didokumentasikan dalam bentuk table 1 dan 2 adalah merupakan hasil wawancara yang dilakukan bersama 2 (dua) orang siswa. Dapa dilihat dari hasil wawancara bahwa para siswa tertarik dengan teknologi yang sedang dikembangkan, alat yang sederhana sebagai peringatan awal kepada siswa untuk tetap menjaga lingkungan tetap bersih.

\section{B. PEDAMUK (Pendeteksi Nyamuk) Sebagai Solusi Mencegah DBD (Demam Berdarah Dengue) Terhadap Anak Sekolah}

PEDAMUK adalah Pendeteksi Nyamuk yang merupakan sebuah inovasi pencegah gigitan nyamuk menggunakan sensor ultrasonik sebagai pendeteksi intetitas atau keberadaan nyamuk guna mencegah anak sekolah dari serangan nyamuk berbahaya atau DBD (Demam Berdarah Dengue). Sebagaimana yang diketahui bahwa lingkungan seko- lah yang kotor atau tumpukan sampah yang dapat menyebabkan nyamuk bersarang dapat menimbulkan beberapa faktor negatif, salah satunya adalah nyamuk yang menyebabkan penderitanya mengidap DBD (Demam Berdarah Dengue). Sebagai solusi efektif PEDAMUK hadir dengan sistem buzzer sebagai tanda keberadaan nyamuk berbasis serial monitor. Ketika alat PEDAMUK di letakkan disuatu tempat kemudian dihidupkan, maka ketika nyamuk terdeteksi serial monitor akan merespon seperti gambar 18 .

\section{Proses Kerja PEDAMUK (Pendeteksi Nyamuk)}

Proses kerja inovasi berbasis teknologi PEDAMUK adalah sebagai berikut :

1. Menentukan dan merangkai semua komponen. Pada gambar 19 dapat dilihat bahwa komponen sudah terakit sesuai dengan rangkaian. Untuk memulai proses kerja dari komponen tersebut maka rangkaian komponen akan disambungkan di Notebook sebagai sistem penerimaan infomaasi nyamuk akan terdeteksi.

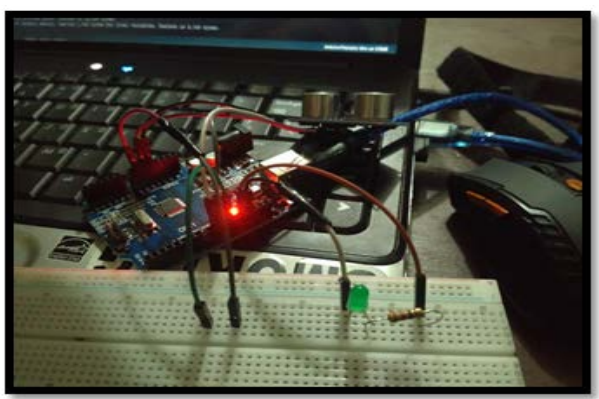

Gambar 19. Inovasi PEDAMUK

Tabel 1. Hasil Interview dari calon pengguna pertama

\begin{tabular}{|l|l|l|l|}
\hline No & \multicolumn{1}{|c|}{ Pertanyaan } & \multicolumn{1}{|c|}{ Jawaban dan Alasan } & Skor \\
\hline 1 & Apakah inovasi ini mudah digunakan? & Mudah, Semoga dapat dikembangkan & 76 \\
\hline 2 & Apakah inovasi ini menarik? & Sangat Menarik & 78 \\
\hline 3 & Apakah Inovasi berguna dalam peran lingkungan? & $\begin{array}{l}\text { Sangat berperan selain menyelamatkan manusia inovasi } \\
\text { ini juga mengharuskan kita untuk menanggulangi sampah } \\
\text { yang bertumpuk di sekolah }\end{array}$ & 77 \\
\hline 4 & Apakah fungsi dari inovasi ini baik? & Sangat Baik & 80 \\
\hline 5 & Apakah sistem dalam inovasi ini optimal? & $\begin{array}{l}\text { Menurut Saya sudah, tapi perlu dikembangkan lagi untuk } \\
\text { lebih optimal dalam penerapannya }\end{array}$ & 74 \\
\hline
\end{tabular}

Tabel 2. Hasil Interview dari calon pengguna kedua

\begin{tabular}{|l|l|l|l|}
\hline No & \multicolumn{1}{|c|}{ Pertanyaan } & \multicolumn{1}{|c|}{ Jawaban dan Alasan } & Skor \\
\hline 1 & Apakah inovasi ini mudah digunakan? & Lumayan Mudah & 73 \\
\hline 2 & Apakah inovasi ini menarik? & $\begin{array}{l}\text { Menarik, menurut saya ini menarik karena mencegah DBD } \\
\text { terjadi dilingkungan sekolah }\end{array}$ & 75 \\
\hline 3 & Apakah Inovasi berguna dalam peran lingkungan? & $\begin{array}{l}\text { Sangat berguna, fungsi untuk kita yang selalu membuang } \\
\text { sampah sembarangan }\end{array}$ & 77 \\
\hline 4 & Apakah fungsi dari inovasi ini baik? & Sangat Baik dan Bagus & 81 \\
\hline 5 & Apakah sistem dalam inovasi ini optimal? & Sudah optimal, sebaiknya di ujipakai sistem android & 70 \\
\hline
\end{tabular}


2. Menyusun program untuk Arduino seperti gambar 20. Pada gambar diatas adalah program integer yaitu sebuah program yang menerapkan konstanta dan bisa diolah untuk mengatur kesesuaian dalam inovasi PEDAMUK. Program ini sebagai kendali dari Inovasi PEDAMUK yang bekerja sesuai dengan ketentuan perintah yang diinginkan

\section{Hasil Pengujian}

Pengujian dilakukan untuk mengetahui bahwa PEDAMUK ini menjadi sebuah inovasi berbasis teknologi yang dapat berfungsi dengan baik sebelum diterapkan dilingkungan sekolah.. Dapat dilihat pada gambar 21, apabila tidak ada nyamuk yang terdeteksi oleh sensor maka buzzer tidak akan berbunyi dan LED menyala, sebaliknya jika ada nyamuk yang terdeteksi oleh sensor maka buzzer akan berbunyi dan LED akan menyala.

\section{E. Estimasi Anggaran Pembuatan Prototipe PEDAMUK}

Pada gambar 22 menampilkan diagram dari rangkaian elektronika PEDAMUK. Sedangkan pada Tabel 3 menampilkan estimasi anggaran yang diperlukan untuk pembuatan purwarupa elektronika PEDAMUK.

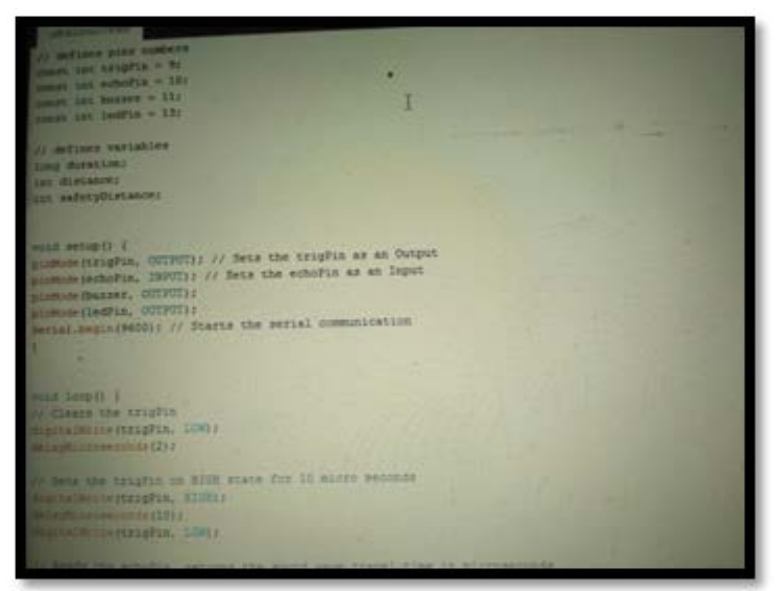

Gambar 20. Program Konstanta Interger

\section{SIMPULAN}

PEDAMUK merupakan solusi yang tepat dalam mengatasi masalah nyamuk, dengan menggunakan sensor ultrasonik untuk mendeteksi suara nyamuk dan intetitas nyamuk yang berkeliaran dilingkungan sekolah. PEDAMUK sangat membantu dalam mencari solusi selanjutnya untuk menanggulangi penyebab timbulnya sarang nyamuk, salah satunya adalah menjaga kebersihan lingkungan dengan membuang sampah pada tempatnya. Proses ini adalah merupakan langkah untuk menciptakan lingkungan sekolah berkualitas menuju revolusi industri 4.0 untuk Indonesia cerdas Penerapan EDP dan proses perancangan yang mengikutsertakan pengguna didalam perancangan bertujuan untuk mendapatkan sebuah inovasi berbasis teknologi yang tepat sasaran, selain itu juga akan memotivasi kepada pengguna untuk berpikir inovatif dan aktif terhadap permasalahan di sekitarnya.

PEDAMUK akan mendeteksi nyamuk, dengan jarak yang dideteksi sejauh $5 \mathrm{~cm}-10 \mathrm{~cm}$ dan bisa disesuaikan dengan sensor jarak yang digunakan. Sensor ultrasonik mendeteksi keberadaan nyamuk dengan serial monitor. Inovasi ini menjadi solusi bagi lingkungan sekolah yang memiliki permasalahan terhadap sampah, penanggulangan dapat diterapkan jika alat ini mendeteksi suatu tempat yang menjadi sarang nyamuk. Dari hasil uji coba bersama pengguna didapatkan bahwa teknologi yang diterapkan dapat diterima dengan mudah dan sesuai dengan kebutuhan, high tech and low cost.

\section{REKOMENDASI}

Pola pikir inovatif dan kreatif dapat dimulai dari tingkat sekolah dasar dan menengah, hal ini telah dibuktikan dengan proses penelitian PEDAMUK, dengan mengikutsertakan siswa

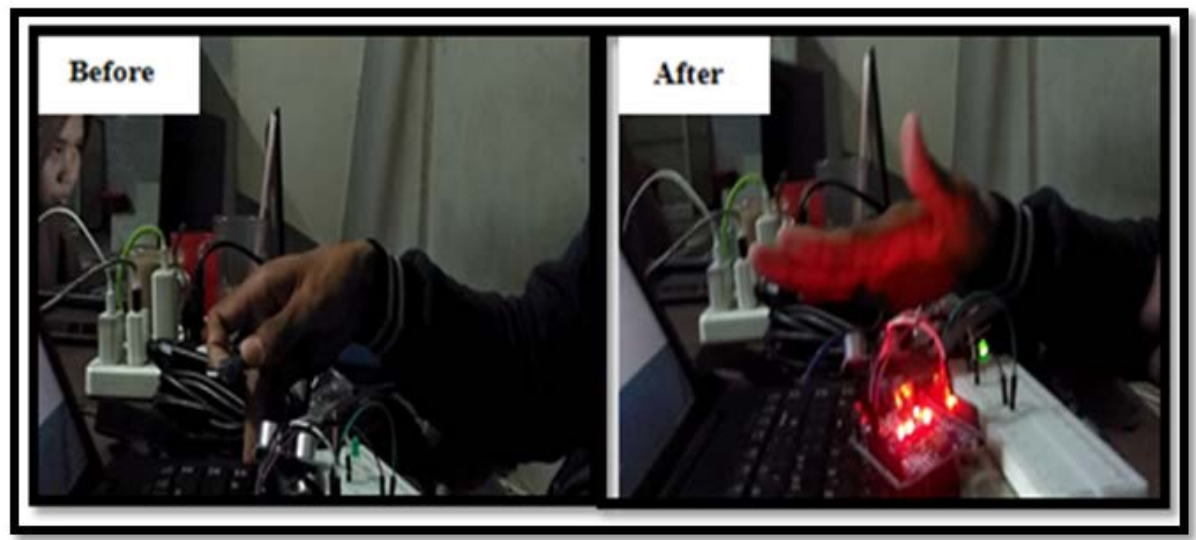

Gambar 21. Hasil pengujian 


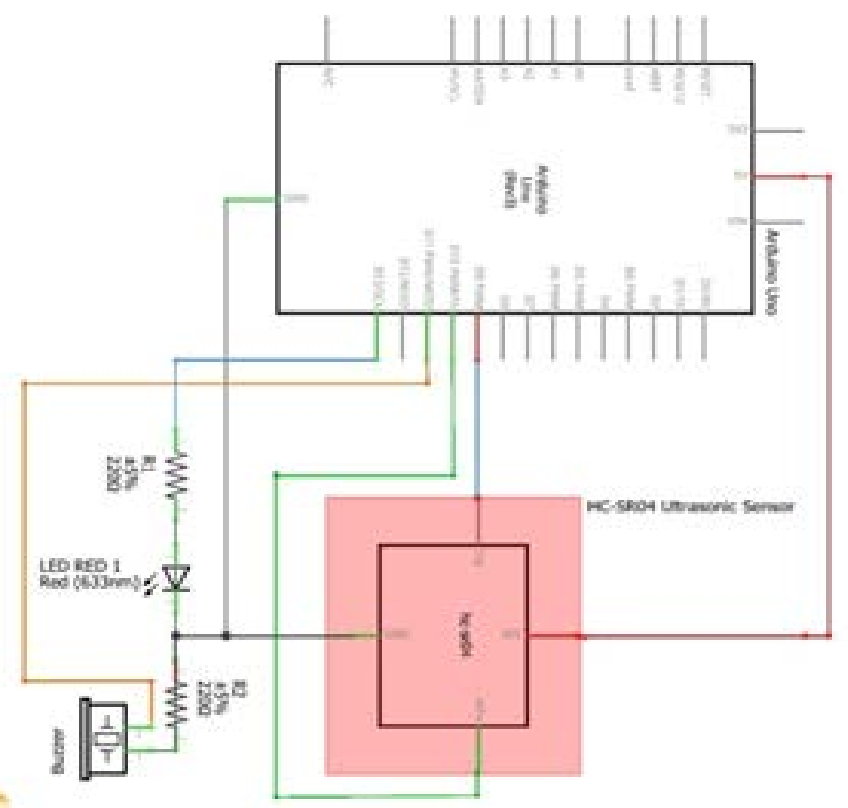

Gambar 21. Diagram rangkaian elektronika PEDAMUK

didalam proses perancangan. Oleh sebab itu, diharapkan kedepannya, inovasi berbasis teknologi yang akan diterapkan pada sebuah lingkungan untuk dapat mengikut sertakan masyarakat sekitar didalam perancangan, sehingga perguruan tinggi akan dapat memberikan kontribusi yang jelas untuk mewujudkan masyarakat berkualitas menuju revolusi industri 4.0 untuk Indonesia cerdas.

\section{DAFTAR PUSTAKA}

KEPUTUSAN MENTERI NEGARA KEPENDUDUKAN DAN LINGKUNGAN HIDUP NOMOR:KEP-02/MENKLH/I/1988 TENTANG PEDOMAN PENETAPAN BAKU MUTU LINGKUNGAN

Pusat Data dan Informasi Kemenkes RI. (2018). Situasi penyakit demam berdarah di Indonesia tahun 2017. InfoDatin. ISSN 2442-7659

Badan Penelitian dan Pengembangan Kesehatan Kemenkes RI. (2016). Situasi penyakit demam berdarah di Indonesia tahun 2017. Jurnal Kesehatan Reproduksi. Vol. 7 No. 2. ISSN 2087-703X

Kampung Bugis Kota Tanjung Pinang [Daring], Tersedia pada https://www. google.com/maps/place/Kampung +Bugis, +Tanjungpinang+City, [ Diakses : 31 Maret 2019 ].
Tabel 3. Estimasi Anggaran (CNC Store Bandung/ Bukalapak, diakses 31 Maret 2019 )

\begin{tabular}{lll}
\hline No & \multicolumn{1}{c}{ Nama Alat } & \multicolumn{1}{c}{ Harga (Rp) } \\
\hline 1 & Arduino Uno & 100.000 \\
2 & Sensor Ultrasonic & 18.500 \\
3 & Project Board & 30.000 \\
4 & Kabel Jumper & 6.000 \\
5 & Resistor & 100 \\
6 & Buzzer & 200 \\
\hline
\end{tabular}

J. Blindheim, A. Wulvik and M. Steinert.(2016) "Using Secondary Video Material for User Observation in The Needfinding Process for New Product Development and Design", International Design Conference - Design 2016

C. Wagner, B. Kawulich, M. Garner.(2012). "Collecting Data Through Observation", Doing Social Research: A global context, McGraw Hill

C. von Saucken, F. Lachner dan U. Lindemann (2014). "Principles for User Experience What We Can Learn from Bad Examples", International Conference on Kansei Engineering \& Emotion Research,

G.I.Johnson, C.W.Clegg dan S.J.Ravden.(1989). "Towards Practical User Experience Evaluation Methods", Applied Ergonomics Volume 20, Edisi 4, Pages 255260, Elsevier Ltd 